Fageda, X., Suau-Sanchez, P., Mason, K. (2015): “The evolving low-cost business model: network implications of fare bundling and connecting flights in Europe". Journal of Air Transport Management 42, 289-296. [10.1016/j.jairtraman.2014.12.002]

\title{
The evolving low-cost business model: network implications of fare bundling and connecting flights in Europe
}

\section{Introduction}

Low-cost travel is becoming the dominant way of flying within Europe (Dobruszkes, 2013). However, there are signs of a slowdown in the organic growth of low-cost carriers (LCC) due to decreasing average frequencies and increasing average route distances, which is forcing LCC to adopt other business strategies for growth (de Wit and Zuidberg, 2012), including the possibility of establishing long-haul low-cost operations (Morrell, 2008) and hybrid low-cost business models (Klophaus et al., 2012). These evolutions make it more difficult to define the LCC business model; in fact, according to Mason and Morrison (2008) several business models coexist and can be categorised under the "low-cost carrier" label. Yet, discussions on long-haul low-cost and hybrid low-cost have developed relatively independently from each other, but both are related with changes in two fundamental principles of the low-cost business model: fare unbundling and point-to-point operations.

The unbundling of fares is one of the characteristics of the archetypical LCC business model. Fare unbundling strategy is aimed at attracting price-sensitive passengers and competing on base ticket fares. In Europe, this strategy can be traced back to easyJet discounting fares for tickets booked through their preferred channel (direct online tickets were discounted at point-of-sale by $£ 2.50$ per sector in 1997), and the introduction of separate fees for various items (by 2005 these included credit card fees, change fees, partner fees, excess baggage and in flight food and beverage). These innovations were introduced to customers as a way of aligning the variable costs borne by the airline to provide such services to the cost of providing them. If a customer does not want to pay for a bag to be carried in the hold, the airline will have lower ground handling costs, which may be reflected in a lower base fare for that customer. All passengers paid a similar base fare, but those looking for a better level of service (e.g., larger leg-room) or additional services (e.g., inflight meals) could purchase them as an ancillary service (i.e., "à la carte fees"). ${ }^{1}$ However, the unbundling strategy is rapidly changing and by 2013 an increasing number of low-cost carriers have introduced a fare category system in order to offer bundles of different services that used to be sold as independent ancillary products. Bundling services can help airlines to standardise their offering and have better control on the level of service provided to the customer, which

\footnotetext{
${ }^{1}$ It should be noted that fare unbundling also existed in the US domestic market and was used by Southwest.
} 
is seen as important for capturing a wider range of passengers and targeting new upmarket segments of the market by the airline.

Another of the fundamental characteristics of the archetypical low-cost business model has been point-to-point service. This allowed for lowering the cost structure by providing a simple operation and management model. Offering point-to-point services also lets airlines schedule their services at the right time of the day to compete with other airlines without being subject to the imperatives of a connecting wave-system. However, this is also changing as some low-cost carriers are starting to connect some of their flights, feeding other airlines and code sharing (e.g., JetBlue in the US has begun codesharing with Emirates, and Air Berlin with Etihad). In a market with limited organic growth, such as Europe, this has a twofold objective. On the one hand, it allows for capturing the increasing number of passengers who already doing self-help hubbing ${ }^{2}$ (O'Connell and Williams, 2005), which can help reducing the route density problem (de Wit and Zuidberg, 2012). On the other hand, allows for connecting more distant markets by feeding the longer flights that the low-cost carrier offers. To take advantage of density economies, the sector distance has ideally been around less than 1,500 Km., which allows for flying as many sectors-a-day as possible and for increasing aircraft utilisation. In relation to the previous point on price bundling, a better level of service and comfort could also contribute to customers withstanding longer travel times.

Although these two key changes have significant consequences on the competitiveness of the low-cost airline business, there is a limited number of new research on the recent changes and evolution of this business model. ${ }^{3}$ In this paper we try to add to the discussion by analysing the network implications of fare bundling and connecting flights in different low-cost carriers models, i.e., archetype low-cost models and hybrid approaches. We aim to identify the influence of several route characteristics on the share that archetype low-cost and adapted low-cost carriers with a hybrid approach have on the routes they operate.

The paper is structured as follows: Section 2 discusses the evolution of the lowcost business model with especial regard to fare bundling and connecting flights, Section 3 introduces the data and the empirical model used for the analysis, Section 4 presents the results of the estimation and, finally, Section 5 discusses the results and their policy implications.

\section{Evolving low-cost business models}

\subsection{Market forces, business models and self-transformation}

\footnotetext{
${ }^{2}$ Self-help hubbing are connections between flights that are not offered by airlines, but that passengers arrange themselves between two independently operated flights. According to Malighetti et al. (2008) two-thirds of the fastest indirect connections in Europe are not operated by the alliance system and could be exploited to enable higher levels of connectivity.

${ }^{3}$ Some examples are Francis et al. (2007), Morrell (2008), Mason and Morrison (2008), Pels (2008), Wensveen and Leick (2009), Douglas (2010), Daft and Albers (2012), and Klophaus et al. (2012)..
} 
The airline industry has been losing value consistently over the last 20 to 30 years and some are starting to recognise that the problems of the airline industry are not just due to cyclical exogenous shocks (Mason and Alamdari, 2007; O'Connell, 2011) or other exogenous cost drivers, such as taxes and fuel (Borenstein, 2011), but that the issue is mainly structural since the gap between long-term returns on capital and cost of capital is widening (Button, 2003; Borenstein, 2011). The long-term financial problems of the airline industry is one of its 'ugliest' aspects (Goetz and Vowles, 2009) that leads to a wide range of fundamental changes that take shape in form of bankruptcies, terminations, mergers and acquisitions.

The reaction of airlines to growing market pressure has been to increase firm's flexibility by decreasing costs, especially those related to labour. However, such measures has not lead to significant changes in the existing business development path of LCC firms; on the contrary, they reinforce the low-cost nature of this type of airline in a sort of continual race to the bottom. Yet, the significance of the 2008 financial crisis could have been a definitive event that fostered the emergence of novelty in the low-cost business model. Business model innovation and technology innovation are the main sources of self-transformation for firms. The creative capacity of economic agents (Boschma and Martin, 2007) to evolve accordingly and to adapt to the selective market forces and changing institutional settings is essential for their survival. In this regard, business models represent a new dimension of innovation, which spans the traditional modes of process, product and organisational innovation, and involves new forms of cooperation and collaboration (Zott et al., 2010). According to Seelos and Mair (2007) the business model is a set of capabilities configured to enable value creation consistent with either economic or social strategic objectives..For the area of our concern, one of the alternative approaches to the archetypical low-cost business model is the adapted business model that takes a hybrid approach.

\subsection{Towards a hybrid approach}

The low-cost airline business model can take a number of forms (Francis et al., 2003; Edwards, 2010) and costs savings can be achieved from different sources (Williams, 2001). While some identify low-cost carriers as those airlines that have a distinctive feature, such as using a single-fare class over their whole network of routes (Fageda and Fernández-Villadangos, 2009), others use other methods, such as the product and organisational architecture (POA) approach, to classify and relate key elements of airline business models (Mason and Morrison, 2008). Be that as it may, the increasing difficulty for defining the low-cost airline business model is, in fact, a sign of the coexistence of several business models that are categorised under the "low-cost carrier" label (Mason and Morrison, 2008; Gross et al., 2013). This is an indication of the existence of some level of institutional plasticity (Strambach, 2010), as airlines try to 
stretch the prevailing institutional agreements and understandings without deviating in excess from the dominant development path of the low-cost carrier business model.

\section{TABLE 1 ABOUT HERE}

Despite that, the level of deviation from the archetypical low-cost business model by some low-cost carriers is starting to be of such a degree that some scholars begin to agree that we might have scope for defining an adapted low-cost carrier business model with a hybrid approach (Franke and John, 2011; Klophaus et al., 2012). Table 1 compares the main practices of the archetypical LCC business model and the adapted LCC business model.

One of the business model deviations that has attracted some academic and industry interest is the possibility of low-cost carriers developing long-haul services. ${ }^{4}$ There is not yet a clear agreement on the viability of a point-to-point low-cost operation for a long-haul service, in other words, a long-haul service without feeding traffic and increasing levels of comfort may be difficult to realise.

Yet, literature shows some conclusions. On the one hand, Pels (2008) concludes that having enough demand might be a key determinant in order to set up low-cost services in long-haul markets. Although this could be seen as a self-evident statement, in fact, this is in line with the long-haul service strategy introduced by Norwegian Air Shuttle, which is mainly based in linking the major markets on both sides of the Atlantic -i.e., London and New York- by taking advantage of the newest and more efficient airliners (Airline Business, 2013). On the other hand, Wensveen and Leick (2009) suggest the existence of an increasing need for interlining agreements and feeding among low-cost carriers, which is in line with AirAsia's considerations that see feeding as a condition for long-haul low-cost services (GAD, 2013).

In this regard, a distinction needs to be made. Firstly, some LCCs conduct some internal feeding, for example, in the US, it is well known that Southwest has a strategy of connecting passengers between its flights in primary airports (Holloway, 2008). A good example in Europe is Vueling, which transfers passengers between its flights in Barcelona (since 2010) and in Rome Fiumicino (since 2014). Since it began transferring passengers in 2010, the airline has internally transferred more than 6 million passengers (IAG, 2014). In other cases, passengers do self-help hubbing without the support of the airline (Malighetti et al., 2008).

Secondly, low-cost carriers not only offer connecting services within themselves, but there are also growing links between low-cost carriers and full-service network carriers, which have been handing over short-haul flights to low-cost carrier subsidiaries.

\footnotetext{
${ }^{4}$ Francis et al. (2007), Morrell (2008) and Moreira et al. (2011) compare the cost advantages of low-cost carriers (LCC), Pels (2008), Wensveen and Leick (2009) and Douglas (2010) assess the suitability of the qualitative features of the LCC business model to the long-haul markets, and Draft and Albers (2012) conduct a profitability analysis.
} 
Among some examples of the increasing interaction between LCC and full-service network carriers (FSNC) we can find Delta buying shares in Gol (2011), Air FranceKLM and Lufthansa have low-cost subsidiaries (Transavia and Germanwings, respectively), Iberia has launched Iberia Express (2012) and is part of the same group as Vueling, and Air Berlin joined the oneworld alliance and is partly owned by Eithad (2012).

In this regard, Fageda et al. (2011) show that a successful strategy of FSNC to compete with LCC is to create their own low-cost subsidiaries. Indeed many European FSNC are substituting their unprofitable short-haul routes with services offered by their LCCs subsidiaries, which have a much lower cost base and can therefore make a profit when operating short-haul routes. For example, Iberia created Iberia Express to circumvent the collective bargaining agreement of Iberia and then pay lower salaries in short-haul routes feeding the hub. Hence, in many cases there is a defined formal strategy and connecting service between the LCC and the FSNC. Yet, in other cases the role of the LCC is not to replace the feeder system of the FSNC, but just to lower the costs and compete with other LCC. For example, Hop!, Germanwings and Transavia are stand-alone point-to-point carriers without a substantial feeding role.

Nevertheless, according to Doganis (2013) the essence of the low-cost business model lays in the point-to-point service, since connecting passengers entails a series of consequences that have ramifications across the airline business competitiveness. For example, airlines might not be able to schedule their services in the most competitive times of the day in order to coordinate inbound and outbound flights in the hub. Nonetheless, the principal driver for implementing transfer services is the increasing number of passengers in a trunk sector, which allows for taking advantage of density economies and helping to overcome the increasing density problem of low-cost markets (de Wit and Zuidberg, 2013). In other words, additional demand can transform a nonfeasible service into a feasible option.

In addition to the point-to-point component, another major core business element of the low-cost business model has been the use of a single-fare class cabin. Indeed, one of the main reasons behind the original success of low-cost carriers was the simplification and unbundling of fares to take advantage of ancillary revenues (Doganis, 2010). Whilst cabin configurations have remained in single configuration, several lowcost carriers have tended to complicate the fare system by including price bundles differentiating the passenger by ticked price and offering them a different range of airport and on-board services (e.g., access to airport lounges, security fast-track, preferential boarding, checked bags, on-board free catering, room reserved in the cabin for hand luggage, etc.). By bundling services low-cost carriers can target higher yield markets, absorb business demand from full-service network carriers (FSNC), secure revenues upfront and differentiate their product from their competitors. More revenues are translated in a movement of the breakeven curve and more routes become feasible. 
Hence, from the main the criteria listed in Table 1, we focus our analysis on what appears to be the most essential ones. Firstly 'transfers between flights', since the essence of the low-cost business model lays in the point-to-point service. Secondly, 'fare bundling', since the main reason behind the original success of low-cost carriers was the simplification and unbundling of fares to take advantage of ancillary revenues.

\section{Empirical model}

The movement towards connecting services and fare unbundling can represent a new development path for the low-cost business model that can change the way competition takes place in the European air transport market. In order to decode the effects of these changes on the network of low-cost carriers, we implement a multivariate analysis to identify the influence of several route characteristics on the share that archetypical and adapted LCC have on the routes of our sample, which includes route-level data for the summer season of 2013. We have Official Airlines Guide (OAG) data for all routes served by direct flights for any airline within the European Union of 27 countries plus Norway and Switzerland. Taking into account that the unit of observations are the routes, our final sample comprises 6,273 observations (routes).

We follow a similar methodological approach as in Fageda and Flores-Fillol (2012a, 2012b). The novelty of our analysis is that it focuses on the differentiation between archetypical low-cost and adapted services with a hybrid approach, whereas the mentioned studies focus on low-cost (not differentiating between archetypical and adapted), regional and FSNC services.

The hybrid approach shares some of the characteristics of the LCC and FSNC business models. From our analysis, we can examine the type of routes where adapted LCC with a hybrid approach are offering services according to features like distance, traffic density or the proportion of leisure travellers. Indeed, we can analyse the similarities or differences between adapted LCC with a hybrid approach and other type of airlines (i.e., archetypical LCC or FSNC) regarding the routes where they offer services. We estimate the following equation for any route $k$ :

Share_type_airline $=\alpha+\beta_{1}$ Dist $_{k}+\beta_{2}$ Seats $_{k}+\beta_{3}$ Dist Centre $_{k}+\beta_{4} D_{k}^{\text {tourism }}+$ $\beta_{5} D_{k}^{\text {hub }}+\beta_{6} D_{k}^{\text {monop }}+\varepsilon_{k}$

Different types of dependent variables are used to account for the proportion of seats that airlines of the considered category (archetypical and adapted LCC) have over the total number of seats in the route. ${ }^{5}$ Data on airline seats at the route level have been obtained from the OAG. These are the three dependent variables depending on the lowcost carrier classification described in Table 2:

\footnotetext{
${ }^{5}$ Alternatively, we could use absolute values for the considered types of airlines. However, our aim is to examine the relative weight of each type of airline operating in the routes of our sample.
} 
1. Share of archetypical low cost carriers (group 1); low cost airlines that only offer point-to-point services and have a single-fare class in their whole network of routes.

2. Share of adapted low-cost carriers with a hybrid approach (group 2); low cost airlines that offer transfer services and usually fare bundling. By 'offering transfer services' we mean that the airline is offering and guaranteeing the connecting service. In other words, that the connections is not informal (i.e., selfhelp hubbing).

3. Share of adapted low-cost carriers with a hybrid approach (group 3); low-cost airlines that only operate point-to-point routes, but offer fare bundling.

Note here that group 1 may be over-influenced by Ryanair, the leading low-cost airline in Europe. Whilst this could be considered as a limitation of our data, we would like to remark that any analysis of archetypical low-cost airlines in Europe will be conditioned upon the strategies followed by Ryanair given their dominant role on this segment of the market.

\section{TABLE 2 ABOUT HERE}

We consider the following as exogenous explanatory variables of the share of the considered category of airlines. Note that the explanatory variables considered are the typical explanatory variables used in empirical analyses about determinants of airline's supply at the route level (see, for example, Bettini and Oliveira, 2008; and Pai, 2010).

1. Dist $t_{k}$ Number of kilometres flown to link the endpoints of the route. We use the great circle distance, which is a proxy of flown distances. Data have been obtained from OAG.

2. Seats $k$ : Total number of seats offered per annum on the route using data provided by OAG. This variable may work as a proxy for route traffic density. The simultaneous determination by airlines of the type of aircraft and the number of seats could imply an endogeneity bias in the estimation. Hence, we apply an instrumental variables procedure to correct for any possible bias. We use the following instruments of the seats variable:

- Pop : Weighted average of population in the route's origin and destination regions.

- $G D P C_{k}$ : Weighted average of GDP per capita in the route's origin and destination regions, with weights based on population.

Data for population and gross domestic product per capita of route endpoints refer to the NUTS 3 regions (the statistical unit used by Eurostat) and have been obtained from Cambridge Econometrics (European Regional Database publication). Traffic density should be higher in more populated 
and wealthier endpoints. Thus, we argue that population and GDP are suitable instruments for the seats variable. Indeed, these two variables are clearly exogenous but, at the same time, they are correlated with the number of seats (correlations are about $20 \%$ for both variables).

3. Dist_centre $k_{k}$ : Sum of the distances between the origin and the destination city centres and their respective airports. Indeed, we constructed an airport access variable that measures the distance between the airport and the city centre using Google Maps. In most cases, the identity of the relevant city was self-evident. However, for airports between cities, we calculated the distance from the airport to the closest city with more than 100,000 inhabitants.

4. $D_{\text {tourism }}$ : Dummy variable that takes the value of one for those routes where at least one of the endpoints is a major coastal tourist destination. All airports on the following islands are considered as tourist destinations: the Balearic and Canary Islands (Spain), Sardinia and Sicily (Italy), Corsica (France), and the Greek islands, together with the airports of Alicante (ALC), Faro (FAO), Malaga (AGP), Nice (NCE) and Saint Tropez (LTT). Note here that data of number of tourists at the NUTS III level is not available. We focus on coastal destinations because only coastal destinations can generate high volumes of air traffic in Europe. As far as we know, any relevant airport is located close to mountains or isolated leisure resorts and we are not able to disentangle the impact of tourism associated with big cities like for example Paris or London with the data available.

5. $D^{h u b}$ : Dummy variable that takes the value one for those airports that are a hub airport of a FSNC. Hub airports are defined as those airports where a FSNC (i.e., an airline integrated in one of the international alliances, Oneworld, Star, Skyteam) has a dominant position and move a high amount of connecting traffic from that airport. We have identified the following hub airports: Amsterdam (AMS), Copenhagen (CPH), Frankfurt (FRA), Helsinki (HEL), London (LHR), Lisbon (LIS), Madrid (MAD), Munich (MUC), Paris (CDG and ORY), Prague (PRG), Rome (FCO), Stockholm (ARN), Vienna (VIE), Warsaw (WAW), and Zurich (ZRH). These airports are characterized by their size and the fact that a FSNC operates a high percentage (usually over half) of all its flights out of them. 6. $D^{\text {monop }}{ }_{k}$ : Dummy variable that takes the value of one for those routes where only one airline is offering services.

Table 3 provides the descriptive statistics of the variables used in the empirical analysis. Low-cost carriers (archetypical or adapted) have a significant market share in the routes of our sample. It is also remarkable the high number of routes that are monopoly routes $(65 \%)$, while $21 \%$ of routes have a hub airport as an endpoint and $34 \%$ of routes have a tourist destination as an endpoint. Finally, the mean route distance is 
1,300 kilometres and most of routes can be considered as short-haul routes. This could have an influence on the results for the variable of distance.

\section{TABLE 3 ABOUT HERE}

It can be anticipated that archetypical low-cost carriers will tend to dominate routes with a high proportion of leisure travellers. Looking at our variables, we can expect that the proportion of leisure travellers is higher in routes that have tourist destinations as endpoints and on routes where airports are further from the city centre. It is also expected that archetypical low-cost carriers will tend to focus their traffic in nonhub airports.

Fageda and Flores-Fillol (2012a) show that archetypical low-cost airlines should dominate longer routes because FSNC may prefer to provide an indirect service (via a hub airport) in city-pair markets where the route distance is sufficiently long. Furthermore, low-cost carriers in Europe tend to dominate thinner routes as it is analysed in Fageda and Flores-Fillol (2012b).

Given the route traffic density issue, it is less clear, a priori, whether archetypical low-cost carriers will dominate monopoly routes or routes subject to competition. Hence, the dummy variable for monopoly routes should be understood as a control variable.

The estimation is made using the generalised linear model with fractional response variables, taking into account the possible endogeneity of the seats variable. ${ }^{6}$ We use this estimation technique because the dependent variable is a percentage that lies between 0 and $1 .^{7}$

\section{Results}

The results of the estimation are shown in Table 4. Column 2 shows the results of the estimation when we use as dependent variable the share of archetypical low-cost carriers. Results are those as expected. In this regard, note that all variables in this regression are statistically significant with the exception of the variable of distance.

The share of archetypical low-cost carriers tends to be higher in longer and thinner routes. Indeed, the coefficient associated to the variable of distance is positive whilst the coefficient associated to the variable of seats is negative. Thus, the share of archetypical low cost carriers increases in routes with more kilometres flown and less seats offered.

\footnotetext{
${ }^{6}$ See Papke and Wooldridge (1996) for details on this econometric method.

7 We also made an estimation for a sub-sample that focuses on routes where low-cost airlines (archetypical or adapted with a hybrid approach) have a market share higher than $50 \%$. This estimation was aimed to identify differences between archetypical LCC and adapted LCC in routes where the share of network airlines is modest or even null. We do not report results for this estimation because they are qualitatively identical to those for the whole sample of routes.
} 
The share of archetypical low cost carriers also increases in routes with a high proportion of leisure travellers. This result comes from the positive sign of the dummy variable for tourist destinations and the positive sign of the variable that measures the distance from the airport to the city centre. Note here that leisure passengers are less sensitive to time than business passengers, therefore the former may have a higher willingness to take flights from secondary airports.

The share of archetypical low cost carriers decreases in routes that do have a hub airport as an endpoint, as the negative sign of the coefficient associated to the dummy variable for hubs shows. Finally, the share of archetypical low-cost carriers is higher in monopoly routes because the coefficient of the dummy variable for monopoly routes is positive.

Columns 3 and 4 show the results of using the share of adatpted airlines of group 2 and 3, respectively, as dependent variables. A clear difference between archetypical low-cost and adapted LCC (either of group 2 or 3 ) is that adapted LCC share is higher in routes that have a hub airport as an endpoint. The sign of the coefficient of the variable of hub airports is negative and statistically significant in the regression that have the share of archetypical low-cost carriers as dependent variable, whilst it is positive and statistically significant when the dependent variable is the share of adapted LCC (either group 2 or 3): i.e., archetypical LCC tend not to use hub airports.

In the same vein, adapted LCC with a hybrid approach tend to have a higher share in routes that have airports close to the city-centre. Indeed, the sign of the coefficient of the variable for the distance to the city-centre is positive and statistically significant in the regression for archetypical low-cost carriers (confirming that archetypical low-cost carriers tend to operate in secondary airports further away from city centres). On the contrary, the sign of the coefficient of this variable is negative in the regressions for adapted LCC, although it is only statistically significant when we consider the share of adapted LCC of group 2 (offering connecting service) as dependent variable. Thus, adapted LCC of group 2 are similar to FSNC in the sense that they tend to channel their flights through hub airports and airports close to big cities.

The use of transfer services by group 2 may also explain the results for the variable of distance. The coefficient associated to this variable is negative and statistically significant in the regression for adapted LCC of category 2 . This means that adapted LCC of group 2 may be offering an indirect service in long city-pair markets or in city-pair markets that do not have an attractive direct connection. Table 5, for example, shows how Vueling is quite successful in channelling via its hub passengers in medium-haul routes (e.g., Ibiza-Moscow) and in short-haul routes that have a limited amount of direct services (e.g., Sevilla-Rome). Otherwise, the coefficient of this variable in the regression of adapted LCC of group 3 (LCC with fare bundling) is positive and statistically significant so that fare bundling in point-to-point routes may be allowing them to operate longer trips. 


\section{TABLE 4 ABOUT HERE}

\section{TABLE 5 ABOUT HERE}

A significant finding is that the strategy of adapted LCC of group 3 (LCC with fare bundling) seems to lead them to higher shares in thicker routes because the sign of the coefficient of the variable of seats is positive and statistically significant in the regression for this type of adapted LCC. Furthermore, fare bundling is likely targeted to attract business passengers because the coefficient for the dummy variable of tourist destinations is negative and statistically significant in the regression for adapted LCC of group 3. Surprisingly, adapted LCC of group 2 (LCC offering connecting services) have a higher share in routes with tourist destinations. In fact, this is the only route feature where adapted LCC of group 2 keep similarities with archetypical low-cost carriers.

Finally, low-cost airlines (either archetypical or adapted) tend to dominate monopoly routes. The coefficient of the dummy for monopoly routes is positive in all regressions although it is not statistically significant in the regression with adapted LCC of group 2 (LCC offering connecting services).

\section{Discussion and conclusions}

The results show that archetypical low-cost and adapted low-cost airlines configure their networks based on different route characteristics. The differences are considerable and suggest that, although there used to be important differences among low-cost carriers (Mason and Morrison, 2008; Graham, 2009), the distance between archetypical low-cost carriers and adapted low-cost carriers with a hybrid approach is starting to widen, after two of the essential features (i.e., fare unbundling and point-to-point operations) of the original low-cost business model have mutated. In fact, our results are in line with other recent studies (Dobruszkes, 2013) that show that the low-cost carrier business is not a single monolithic model.

The evolution of business models is the result of the indispensable realignment of resources after consolidation (Franke, 2007) and of the limits to organic growth (de Wit and Zuidberg, 2013). In this regard, although visits to friends and relatives (VFRs) and holidays have been largely associated with low-cost travel (Dobruszkes, 2013) because of the role of airfares in travel decision (O'Connell and Williams, 2005)-, business travellers have used low-cost airlines since the early days, especially for the value for money that they provide for short sales visits and for small- and medium-sized companies (Mason, 2001; Mason and Alamdari, 2007). The inclusion of the fare bundling, together with other strategic movements, such as the deal of easyJet to extend the airline's offerings among corporate travellers through BCD Travel's Global Network (easyJet, 2014) or the access to VIP lounges across Europe to holders of the 
Vueling Passcard (Vueling, 2012), shows that adapted LCC with a hybrid approach could be able to continue drawing traffic away from FSNC.

Overall, the key matter is that adapted LCC are changing the traditional revenue structure, based in ancillary revenues, in order to continue growing and attracting new passengers. Although our empirical analysis is a cross-sectional examination, we can deduce that this change translates in different network characteristics for those low-cost carriers offering fare bundling options (Table 6), which is consistent with Dobruszkes' (2013) findings, who found an evolution towards a wider range of low-cost networks. By offering a range of onboard bundled services and a higher level of comfort to passengers, these airlines are able to provide longer routes in medium-haul markets that can be sustained by a certain level of demand.

In this regard, connections between flights can also help to overcome the barrier to entry to longer medium-haul flights (Francis et al., 2007), partly solving the route density problem of the point-to-point low-cost carrier (de Wit and Zuidberg, 2013). Indeed, for some adapted LCC connecting passengers account for a not inconsiderable amount (e.g., 11\% of Vueling's passengers are connecting). Connections within Europe might not be attractive for the business passenger, but can be an option for leisure travellers.

\section{TABLE 6 ABOUT HERE}

The results of this paper are also relevant from an airport policy and strategy point of view. Whilst airport profiles have been quite polarised in three main types (i.e., big hub airports, secondary airports and legacy airports in transition ${ }^{8}$, and regional airports), because of the archetypical contrasting airline business models (ultra low-cost, low-cost, and full service), the evolution of the low-cost business model towards more hybrid versions can open new business and growth opportunities for airports. This is especially relevant for secondary airports and legacy airports in transition that could be able to reduce the gap between them and the main hub airports. But it requires of airports to understand that they are not exclusively providers of infrastructure anymore, but that the successful airport will be a network manager. In other words, active airports in the commercial (e.g., route development), management (e.g., airport charges, facilitating self-help hubbing and inter-carrier connections), planning (e.g., terminal design), air traffic management (e.g., gate allocation, facilitate trouble-free transfers), and customer experience (e.g., seamlessness travel, lounges, etc.) dimensions will be able to cater to adapted LCC with a hybrid approach and establish themselves as new

\footnotetext{
${ }^{8}$ A legacy airport in transition is an airport that lost a significant amount of traffic from full service network carriers after the EU air transport market deregulation and that has more than one third of LCC market share (See Jimenez et al. (2013) for a characterization of low-cost airports).
} 
strong players in the airport market. This returns us to the evolutionary concept of selftransformation presented in Section 2.1 and the need for adaptation in order to survive.

A good example of an airport adapting its strategy to the evolving airline market developments is Düsseldorf International, which has even trademarked the term "Next Generation Hub" (Topp, 2012). Instead of relying on mainly one dominant carrier (either full service or low-cost), the airport is trying to capitalise on a mix of carriers (e.g., Lufthansa, Air Berlin, TUIfly, etc.) and also attract other foreign carriers (e.g., Emirates, Etihad, Air China, Orenair, etc.), understanding that connecting passengers are their key growth factor. Gatwick Airport has also introduced a facilitated connections services for passengers wishing to connect between airlines that do not offer a connection service.

Hence, airline market consolidation in Europe will continue in form of efficient airlines surviving by filling capacity gaps. From a strategy point of view, this means that increasing co-evolution and airline-airport collaboration in terms of route development, long-term agreements, and revenue sharing arrangements will be needed to ensure future air traffic stability and growth for both airlines and airports (see, for example, CAPA (2012).

Further research on hybrid approaches could expand the findings presented in this paper into other areas, such as the revenue and cost structure implications of these business model evolution, the contribution that connecting services can do to long-haul operations and how competition between low-cost and full-service network carriers might be changing.

\section{References}

Airline Business, 2013. Interview to Bjørn Kjos, Viking Raider. Airline Business 29(7), 20-25.

Bettini, H.F.A.J., Oliveira, A.V.M., 2008. Airline capacity setting after re-regulation: The Brazilian case in the early 2000s. Journal of Air Transport Management, 14, 289-292.

Borenstein, S., 2011. Why can't US airlines make money? American Economic Review: Papers \& Proceedings 101, 233-237.

Boschma, R.A., Martin, R., 2007. Editorial: Constructing an evolutionary economic geography, Journal of Economic Geography 7, 537-548.

Button, K., 2003. Does the theory of the 'core' explain why airlines fail to cover their long-run costs of capital? Journal of Air Transport Management 9, 5-14.

CAPA, 2012. Airlines in transition: Hybrid and low-cost carriers push for better airlineairport relationships. CAPA Centre for Aviation, 25 January 2012. URL: http://centreforaviation.com/analysis/airlines-in-transition-hybrid-and-low-costcarriers-push-for-better-airline-airport-relationships-66599

Daft, J., Albers, S., 2012. A profitability analysis of low-cost long-haul flight operations. Journal of Air Transport Management 19, 49-54.

De Wit, J., Zuidberg, J., 2012. The growth limits of the low cost carrier model. Journal of Air Transport Management 21, 17-23. 
Dobruszkes, F., 2013. The geography of European low-cost airline networks: a contemporary analysis. Journal of Transport Geography 28, 75-88.

Doganis, R., 2010. Flying off course: airline economics and marketing. Routledge, London.

Doganis, R., 2013. Strategies for Survival - Evolving Airline Business Models. Air Transport Management Seminar, Cranfield University, 11 November 2013.

Douglas, I., 2010. Long-haul market entry by value-based airlines: dual business models support product innovation. World Review of Intermodal Transportation Research 3, 202-214.

easyJet, 2014. Press Release: Easyjet signs Europe-wide deal with BCD Travel, opening access to corporate travellers. 17 February 2014. URL: corporate.easyjet.com/media

Edwards, J.E., 2010. Key characteristics and attitudes of airline passengers, with particular emphasis upon the low-cost sector: implications for pre-trip decisionmaking and airline choice. PhD Thesis. School of Architecture and the Built Environment, University of Westminster.

Fageda, X., Fernández-Villadangos, L., 2009. Triggering competition in the Spanish airline market: the role of airport capacity and low cost carriers, Journal of Air Transport Management 15, 36-40.

Fageda, X., Flores-Fillol, R., 2012a. On the optimal distribution of traffic of network airlines. European Economic Review 56, 1164-1179.

Fageda, X., Flores-Fillol, R., 2012b. Air services on thin routes: Regional versus lowcost airlines. Regional Science and Urban Economics 42, 702-714

Fageda, X., Jiménez, J.L, Perdiguero, J., 2011. Price rivalry in airline markets: A successful strategy of a network carrier against a low-cost carrier, Journal of Transport Geography, 19, 658-669

Francis, G., Fidato, A., Humphreys, I., 2003. Airport-airline interaction: the impact of low-cost carriers on two European airports. Journal of Air Transport Management 9, 267-273.

Francis, G., Dennis, N., Ison, S., Humphreys, I., 2007. The transferability of the low cost model to long-haul airline operations. Tourism Management 28, 391-398.

Franke, M., 2007. Innovation: The winning formula to regain profitability in aviation? Journal of Air Transport Management 13, 23-30.

Franke, M., John, F., 2011. What comes next after recession? - Airline industry scenarios and potential end games. Journal of Air Transport Management 17, 19-26.

GAD, 2013. Meet the industry pace setters. Panel session with Justin Erbacci (StarAlliance), Senthil Balan Danabalan (AirAsia), and Javier Suarez Casado (Vueling). 20 ${ }^{\text {th }}$ Global Airport Development Conference, 5-7 November 2013, Nice.

Goetz, A.R., Vowles, T., 2009. The good, the bad, and the ugly: 30 years of US airline deregulation. Journal of Transport Geography 17, 251-263.

Graham, M., 2009. Different models in different spaces or liberalized optimizations? Competitive strategies among low-cost carriers. Journal of Air transport Management 16, 127-136.

Gross, S., Lück M., Schröder, A., 2013. The Low Cost Carrier - A Worldwide Phenomenon IN Gross,S., Harz, H., "The Low Cost Carrier Woldwide" Aldershot: Ashgate, p. 3-15.

Holloway, S., 2008. Straight and Level. Practical Airline Economics. Third Edition. Aldershot, Ashgate.

IAG, 2014. International Airlines Group. Capital Markets Day presentation. 7 November 2014. 
Jimenez, E., Claro, J., Pinho de Sousa, J., de Neufville, R., 2010. A tale of two airports: demystifying "low-cost" in European aviation. Presentation at the Air Transport Research Society Conference 2010. 10 July 2010, Porto.

Klophaus, R., Conrady, R., Fichert, F., 2012. Low cost carriers going hybrid: evidence from Europe. Journal of Transport Management 23, 54-58.

Malighetti, P., Paleari, S., Redondi, R., 2008. Connectivity of the European airport network: "Self-help hubbing" and business implications. Journal of Air Transport Management 14, 53-65.

Mason, K.J., 2001. Marketing low-cost airline services to business travellers. Journal of Air Transport Management 7, 103-109.

Mason, K.J., Alamdari, F., 2007. EU network carriers, low-cost carriers and consumer behaviour: A Delphi study of future trends. Journal of Air Transport Management 13, 299-310.

Mason, K.J., Morrison, W.G., 2008. Towards a means of consistently comparing airline business models with an application to the 'low-cost' airline sector. Research in Transportation Economics 24, 75-84.

Moreira, M.E., O'Connell, J.F., Williams, G., 2011. The viability of long-haul, low-cost business models. Journal of Air Transport Studies 2, 69-91.

Morrell, P., 2008. Can long-haul low-cost airlines be successful? Research in Transportation Economics 24, 61-67.

O'Connell, F., Williams, G., 2005. Passengers' perceptions of low cost airlines and full service carriers: a case study involving Ryanair, Aer Lungus, Air Asia and Malaysian Airlines. Journal of Air Transport Management 11, 259-272.

Pai, V., 2010. On the factors that affect airline flight frequency and aircraft size. Journal of Air Transport Management 16, 169-177.

Papke, L., Wooldridge J., 1996. Econometric methods for fractional response variables with an application to $401(\mathrm{k})$ plan participation rates. Journal of Applied Econometrics, 11, pp. 619-632.

Pels, E., 2008. Airline network competition: full-service airlines, low-cost airlines and long-haul markets. Research in Transportation Economics 24, 68-74.

Seelos, C., Mair, J., 2007. Profitable business models and market creation in the context of deep poverty: a strategic view. Academy of Management Perspectives 21 49-63.

Strambach, S., 2010. Path dependency, path plasticity-the co-evolution of institutions and innovation. The German business software industry. In: Boschma, R.A., Martin, R. (Eds.), Handbook for Evolutionary Economic Geography. Edward Elgar, Cheltenham, pp. 406-431.

Topp, U., 2012. Düsseldof International - Next Generation Hub ${ }^{\mathrm{TM}} .6^{\text {th }}$ Annual Airneth Conference. 19 April 2012, The Hague. URL: www.airneth.com

Vueling, 2012. Press release: Vueling extends the range of business services with Vueling Pass. 3 August 2012. URL: www.vueling.com/en/we-are-vueling/pressroom

Wensveen, J.G., Leick, R., 2009. The long-haul low-cost carrier: a unique business model. Journal of Air Transport Management 15, 127-133.

Williams, G., 2001. Will Europe's charter carriers be replaced by 'no-frills' scheduled airlines? Journal of Air Transport Management 7, 277-286.

Zott, C., Amit, R., Massa, L., 2010. The business model: theoretical roots, recent developments, and future research. IESE Business School Working Paper WP-862. 
Table 1. Archetypical and adapted low-cost carrier business model practices.

Source: Authors' own elaboration from Mason and Morrison (2008), Klophaus et al. (2012) and Doganis (2013).

Archetypical LCC

\begin{tabular}{lll}
\hline Fleet & Single type & approach \\
\hline Aircraft type & Narrow body & Single type or mix \\
\hline Type of airport & $\begin{array}{l}\text { Regional (Ultra LCC) and/or } \\
\text { primary and/or secondary }\end{array}$ & $\begin{array}{l}\text { Narrow body and wide body } \\
\text { for long-haul }\end{array}$ \\
\hline Code sharing & No & Can provide code sharing \\
\hline $\begin{array}{l}\text { Transfer between flights and } \\
\text { feeding services }\end{array}$ & No & $\begin{array}{l}\text { Can provide transfer between } \\
\text { flights }\end{array}$ \\
\hline Member of global alliance & No & Can be member \\
\hline Sector length & Ideally from 500 to 1,500 Km. & Can be longer than 2,000 Km. \\
\hline Long-haul flights & No & Can be long-haul \\
\hline Single class cabin & Yes & Yes \\
\hline Fare bundling & No & $\begin{array}{l}\text { Yes, different fare bundles } \\
\text { offering different levels of }\end{array}$ \\
& & service \\
\hline Sales distribution channel & Mostly internet & Mostly internet, but also GDS \\
\hline Frequent flyer programme & No & Can offer FFP \\
\hline Frills* & No frills & Depending on fare bundle \\
\hline
\end{tabular}

*Frills may include, among others: complimentary in-flight services, free checked baggage, room reserved on the aircraft for hand luggage, food on board, free flight changes, exclusive check-in desks, etc. 
Table 2. Low-cost carrier classification according to fare bundle and connecting flights (2013).

\begin{tabular}{|c|c|c|}
\hline & $\begin{array}{c}\text { Fare bundle } \\
\text { (Flexible options for flight changes not } \\
\text { considered) }\end{array}$ & Connecting flights \\
\hline \multicolumn{3}{|c|}{ Group 1: Archetypical low-cost carrier } \\
\hline Air One & No & No \\
\hline Blue Air & No & No \\
\hline Corendon Airlines & No & No \\
\hline Jet2.com & No & No \\
\hline Ryanair & No & No \\
\hline Transavia & No & No \\
\hline \multicolumn{3}{|c|}{ Group 2: Adapted low-cost carriers offering connecting flights and usually fare bundling } \\
\hline airBaltic & Basic, Economy, Business & Yes \\
\hline AirBerlin and Niki & JustFly, FlyDeal, FlyClassic, FlyFlex & Yes \\
\hline Germanwings & Basic, Smart & Yes \\
\hline Flybe & Essentials, New Economy, Plus & Yes \\
\hline Norwegian & - & Yes \\
\hline Vueling & Basic, Optima, Excellence & Yes \\
\hline \multicolumn{3}{|c|}{ Group 3: Adapted low-cost carriers offering fare bundling, but not connecting flights } \\
\hline Easyjet & Economy, Plus & No \\
\hline Wizz Air & Premium & No \\
\hline
\end{tabular}


Table 3. Descriptive statistics of the variables used in the empirical analysis

\begin{tabular}{|c|c|c|}
\hline & Mean & Standard deviation \\
\hline $\begin{array}{c}\text { Share of archetypical low } \\
\text { cost carriers (group 1) }\end{array}$ & 0.43 & 0.47 \\
\hline $\begin{array}{c}\text { Share of adapted } \\
\text { (group 2) }\end{array}$ & 0.19 & 0.36 \\
\hline $\begin{array}{c}\text { Share of adapted } \\
\text { (group 3) }\end{array}$ & 0.23 & 0.38 \\
\hline Distance & $1,361.16$ & 776.82 \\
\hline Seats per annum & $68,245.62$ & $128,913.1$ \\
\hline D $^{\text {tourism }}$ & 0.34 & 0.47 \\
\hline Distance_to_citycenter & 45.62 & 29.23 \\
\hline D $^{\text {monopoly }}$ & 0.65 & 0.47 \\
\hline D $^{\text {hub }}$ & 0.21 & 0.41 \\
\hline
\end{tabular}


Table 4. Results of estimates of different categories of low-cost carriers (all sample). Generalised linear model with fractional response variables.

\begin{tabular}{|c|c|c|c|}
\hline & $\begin{array}{c}\text { Dependent variable: } \\
\text { Share of } \\
\text { archetypical low } \\
\text { cost carriers - } \\
\text { group } 1\end{array}$ & $\begin{array}{l}\text { Dependent variable: } \\
\text { Share of adapted LCC - } \\
\text { group } 2 \text { (at least } \\
\text { connecting flights) }\end{array}$ & $\begin{array}{l}\text { Dependent variable: Share } \\
\text { of adapted LCC - group } 3 \\
\text { (only fare bundling) }\end{array}$ \\
\hline \multirow[t]{2}{*}{ Distance } & $5.82 \mathrm{e}-06$ & -0.0004 & 0.0004 \\
\hline & $(0.00005)$ & $(0.00005) * * *$ & $(0.00004) * * *$ \\
\hline \multirow[t]{2}{*}{ Seats } & $-2.13 e-06$ & $-1.48 \mathrm{e}-06$ & $6.45 \mathrm{e}-06$ \\
\hline & $(1.09 \mathrm{e}-06)^{* * *}$ & $(1.21 \mathrm{e}-06)$ & $(9.80 \mathrm{e}-07)^{* * *}$ \\
\hline \multirow[t]{2}{*}{$D^{\text {tourism }}$} & 0.17 & 0.12 & -0.28 \\
\hline & $(0.04)^{* * *}$ & $(0.04)^{* * *}$ & $(0.04)^{* * *}$ \\
\hline \multirow{2}{*}{$\begin{array}{c}\text { Distance_to_cityce } \\
\text { ntre }\end{array}$} & 0.007 & -0.016 & -0.00017 \\
\hline & $(0.0006)^{* * *}$ & $(0.001)^{* * *}$ & $(0.0006)$ \\
\hline \multirow[t]{2}{*}{$D^{\text {monopoly }}$} & 0.72 & 0.052 & 0.81 \\
\hline & $(0.12)^{* * *}$ & $(0.13)$ & $(0.11)^{* * *}$ \\
\hline \multirow[t]{2}{*}{$\mathbf{D}^{\text {hub }}$} & -0.54 & 0.13 & 0.11 \\
\hline & $(0.06)^{* * *}$ & $(0.06)^{* *}$ & $(0.05)^{* * *}$ \\
\hline \multirow[t]{2}{*}{ Constant } & -0.84 & 0.27 & -2.26 \\
\hline & $(0.19)^{* * *}$ & $(0.20)$ & $(0.17)^{* * *}$ \\
\hline AIC & 1.12 & 0.84 & 0.98 \\
\hline BIC & -48334.62 & -50033.51 & -49372.79 \\
\hline $\mathbf{N}$ & 6273 & 6273 & 6273 \\
\hline
\end{tabular}

Note 1: Standard errors in parenthesis (robust to heteroscedasticity)

Note 2: Statistical significance at $1 \%(* * *), 5 \%(* *), 10 \%(*)$ 
Table 5. Vueling Airlines' top airport-pairs in terms connecting passengers at Barcelona Airport, Summer Season 2013. Source: MIDT.

\begin{tabular}{|l|c|}
\hline Airport-pairs & Connecting Passengers at Barcelona Airport (two ways) \\
\hline Sevilla-Rome Fiumicino & 6,160 \\
\hline Ibiza-Menorca & 4,034 \\
\hline Sevilla-Palma de Mallorca & 3,737 \\
\hline Ibiza-Moscow & 3,698 \\
\hline Nice-Palma de Mallorca & 3,107 \\
\hline Sevilla-Menorca & 3,205 \\
\hline Sevilla-Ibiza & 3,192 \\
\hline Asturias-Menorca & 3,016 \\
\hline Malaga-Menorca & 2,815 \\
\hline Stockholm-Ibiza & 2,800 \\
\hline Paris Orly-Gran Canaria & 2,783 \\
\hline Alicante-Palma de Mallorca & 2,752 \\
\hline Malaga-Palma de Mallorca & 2,728 \\
\hline Granada-Menorca & 2,709 \\
\hline Palma de Mallorca-Madrid & 2,698 \\
\hline
\end{tabular}


Table 6. Summary of results: low-cost airline business model network characteristics.

\begin{tabular}{|l|l|l|l|}
\hline & Archetypical LCC & $\begin{array}{l}\text { Adapted LCC } \\
\text { offering connecting } \\
\text { services }\end{array}$ & $\begin{array}{l}\text { Adapted LCC } \\
\text { offering fare } \\
\text { bundling }\end{array}$ \\
\hline $\begin{array}{l}\text { Route density (seats } \\
\text { per annum) }\end{array}$ & Thin routes & $\begin{array}{l}\text { Thin and thick } \\
\text { routes }\end{array}$ & Thick routes \\
\hline Route length & Longer routes & Shorter routes & Longer routes \\
\hline Route competition & Monopoly routes & $\begin{array}{l}\text { More exposed to } \\
\text { competition }\end{array}$ & Monopoly routes \\
\hline $\begin{array}{l}\text { Operation at hub } \\
\text { airports }\end{array}$ & No & Yes & Yes \\
\hline $\begin{array}{l}\text { Airport distance to } \\
\text { city centre }\end{array}$ & $\begin{array}{l}\text { Far from city } \\
\text { centres }\end{array}$ & Close to city centres & $\begin{array}{l}\text { Likely to be close to } \\
\text { city centres }\end{array}$ \\
\hline $\begin{array}{l}\text { Coastal Tourist } \\
\text { destinations }\end{array}$ & Yes & Yes & No \\
\hline
\end{tabular}




\section{The evolving low-cost business model: network implications of fare bundling and connecting flights in Europe}

\section{Fageda, Xavier}

\section{Elsevier}

Fageda X, Suau-Sanchez P, Mason KJ. (2015) The evolving low-cost business model: network implications of fare bundling and connecting flights in Europe. Journal of Air Transport

Management, Volume 42, January 2015, pp. 289-296

https://doi.org/10.1016/j.jairtraman.2014.12.002

Downloaded from Cranfield Library Services E-Repository 